\title{
PENGARUH PERTUMBUHAN EKONOMI DAN PENGELUARAN PEMERINTAH TERHADAP PENYERAPAN TENAGA KERJA SERTA KESEJAHTERAAN MASYARAKAT DI PROVINSI BALI
}

\author{
Ni Putu Ambar Pratiwi ${ }^{1}$ \\ I Gusti Bagus Indrajaya ${ }^{2}$ \\ ${ }^{1,2}$ Fakultas Ekonomi dan Bisnis Universitas Udayana (Unud), Bali, Indonesia \\ E-mail: ambarpratiwi97@gmail.com
}

\begin{abstract}
The Effect of Economic Growth and Government Expenditures on Absorption of Labor and Public Welfare in the Province of Bali. This study aims to determine the condition of employment in the Province of Bali, analyzing the effect of economic growth and government expenditure on employment and community welfare. This data is obtained from the Central Statistics Agency of Bali province. The analysis technique used is Path Analysis. The results showed that economic growth had a positive and insignificant influence on the absorption of employment in the province of Bali and government expenditure had a positive and significant effect on employment in the Province of Bali. Government expenditure and employment have a positive and significant influence on the welfare of the people in Bali Province while economic growth has a non-significant effect on people's welfare. Labor absorption mediate economic growth towards the welfare of the people in Bali Province while the absorption of labor does not mediate government spending on the welfare of the people in Bali Province in 2013-2017.
\end{abstract}

Keywords: economic growth; government expenditure; employment; human development index.

\begin{abstract}
Abstrak : Pengaruh Pertumbuhan Ekonomi dan Pengeluaran Pemerintah Terhadap Penyerapan Tenaga Kerja Serta Kesejahteraan Masyarakat di Provinsi Bali. Penelitian ini bertujuan untuk mengetahui kondisi ketenaga kerjaan di Provinsi Bali, menganalisis pengaruh pertumbuhan ekonomi dan pengeluaran pemerintah terhadap penyerapan tenaga kerja serta kesejahteraan masyarakat. Data ini diperoleh dari Badan Pusat Statistik provinsi Bali. Teknik analisis yang digunakan adalah Path Analysis. Hasil penelitian menunjukkan bahwa Pertumbuhan ekonomi tidak memiliki pengaruh positif terhadap penyerapan tenga kerja di provinsi Bali. Sedangkan pengeluaran pemerintah berpengaruh positif dan signifikan terhadap penyerapan tenaga kerja di Provinsi Bali. Pengeluaran pemerintah dan penyerapan tenaga kerja memiliki pengaruh positif dan signifikan terhadap kesejahteraan masyarakat di Provinsi Bali, dan pertumbuhan ekonomi tidak memiliki pengaruh positif terhadap kesejahteraan masyarakat di Provinsi Bali. Penyerapan tenaga kerja memediasi pengaruh pertumbuhan ekonomi terhadap kesejahteraan masyarakat di Provinsi Bali, sedangkan penyerapan tenaga kerja tidak memediasi pengaruh pengeluaran pemerintah terhadap kesejahteraan masyarakat di Provinsi Bali tahun 2013-2017.
\end{abstract}

Kata Kunci: pertumbuhan ekonomi; pengeluaran pemerintah; penyerapan tenaga kerja; indeks pembangunan manusia. 


\section{PENDAHULUAN}

Pembangunan diartiakan sebagai perekonomian untuk mengembangkan kegiatan perekonomiannya sehingga infrastruktur lebih banyak tersedia, perusahaan semakin banyak dan kian berkembang, taraf pendidikan yang semakin tinggi dan kemajuan teknologi semakin meningkat. Sebagai implikasi dan perkembangan ini diharapkan kesempatan kerja akan bertambah, tingkat pendapatan meningkat dan kemakmuran masyarakat semakin tinggi (Sukirno,2011).

Pembangunan ekonomi tidak terlepas dari pertumbuhan ekonomi, pembangunan ekonomi mendorong pertumbuhan ekonomi dan sebaliknya pertumbuhan ekonomi memperlancar proses pembangunan ekonomi. Pembangunan merupakan upaya perubahan struktural yang bertujuan untuk meningkatkan produktivitas dan menciptakan kesempatan kerja yang akhirnya akan meningkatkan pendapatan penduduk, tujuan dari pembangunan ekonomi sendiri untuk menciptakan kehidupan masyarakat yang adil dan makmur. Mengeksplorasi tantangan pertumbuhan ekonomi yang dihadapi oleh ekonomi yang melimpah dalam tenaga kerja dan sumber daya alam dalam ekonomi global yang semakin maju,bahwa penghargaan spesialisasi yang semakin didominasi oleh beberapa negara berkembang yang sangat besar, terutama Cina (Coxhead,2008). Beberapa langkah yang dilakukan oleh pemerintah dalam mencapai sasaran tujuan pembangunan adalah dengan mengentaskan kemiskinan, pemerataan pendapatan, serta penyediaan lapangan pekerjaan.

Menurut Schumpeter dalam Boediono (2012:48) Pertumbuhan ekonomi diartikan sebagai peningkatan output masyarakat yang disebabkan oleh semakin banyak faktor produksi yang dipergunakan dalam proses produksi tanpa ada perubahan cara-cara teknologi itu sendiri. Indikator pertumbuhan ekonomi tidak hanya mengukur tingkat pertumbuhan output dalam suatu perekonomian, namun memberikan indikasi sejauh mana aktifitas perekonomian yang terjadi pada periode tertentu yang telah menghasilkan pendapatan bagi masyarakat. Masalah penyerapan tenaga kerja menunjukan bahwa semakin tinggi angka pengangguran maka akan meningkatkan kemiskinan, kriminalitas, dan fenomena-fenomena sosial-ekonomi di masyarakat.Penyerapan tenaga kerja yaitu jumlah orang yang bekerja di berbagai sektor, jumlah dan komposis tenaga kerja akan secara terus menerus mengalami perubahan seiring dengan perubahan demografi. Jumlah pekerja menurut lapangan pekerjaan merupakan suatu ukuran untuk melihat serta mengetahui potensi sektor perekonomian mana yang memberikan kontribusi paling besar terhadap penyerapan tenaga kerja dan mencerminkan struktur perekonomian di suatu daerah.

Penyerapan tenaga kerja merupakan salah satu pendukung pembangunan ekonomi yang dilakukan oleh negara-negara berkembang dan mempunyai tujuan antara lain untuk menciptakan pembangunan ekonomi secara merata (Shimer,2005). Penyerapan tenaga kerja adalah diterimanya para pelaku tenaga kerja untuk melakukan tugas sebagaimana mestinya atau adanya suatu keadaaan yang menggambarkan tersedianya pekerja atau lapangan pekerjaan untuk diisi oleh pencari kerja, dengan skill dan kemampuan yang dimiliki, diharapkan nantinya penduduk usia muda akan terserap dalam pasar tenaga kerja. Namun seiring berkembangnya zaman dan memasuki era perdagangan bebas ternyata apa yang diharapkan tidaklah sesuai dengan kenyataannya. Ketidakseimbangan antara permintaan dan penawaran tenaga kerja dalam hal ini supply lebih besar daripada demand tentunya menimbulkan masalah pengangguran.

Tujuan otonomi daerah diarahkan untuk kesejahterahan masyarakat dan peningkatan kualitas pelayanan publik. Wegner (dalam Soetrisno 1984) menyatakan bahwa pengeluaran pemerintah akan selalu meningkat seiring dengan meningkatnya kegiatan-kegiatan pemerintah dalam rangka memacu laju pertumbuhan ekonomi. Ini salah satu dari tujuan pelaksanaan otonomi daerah yang diimplementasikan pada pengeluaran belanja rutin. Kenaikan pengeluran pemerintah yang direncankan akan menyebabkan penambahan permintaan agregat, dimana permintaan agregat akan mendorong produksi barang dan jasa yang akan menyebabkan pendapatan juga akan meningkat. Kebijakan distribusi pengeluaran pemerintah yang tepat sasaran dan ketepatan arah investasi ke daerah-daerah yang dapat menciptakan kesempatan kerja akan meningkatkan pertumbuhan ekonomi. Swaramarinda (2011) 
menyatakan kekuatan pengaruh pengeluaran pemerintah terhadap pembangunan manusia harus bisa mengidentifikasi sektor prioritas seperti pendidikan dan kesempatan kerja yang mempunyai potensi paling tinggi untuk meningkatkan pembangunan manusia. Pertumbuhan pendapatan adalah salah satu sebagai kontributor utama untuk langsung meningkatkemampuan individu dan akibatnya perkembangan manusia bangsa sejakini merangkum perintah ekonomi atas sumber daya (Ranis, 2004).

Pengeluaran pemerintah sendiri merupakan alat intervensi pemerintah terhadap perekonomian yang dianggap paling efektif. Keberhasilan pembangunan di suatu daerah disamping ditentukan oleh besarnya pengeluaran pemerintah tersebut juga dipengaruhi oleh besarnya investasi. Investasi merupakan salah satu pilar pertumbuhan ekonomi, investasi dapat menjadi titik tolak bagi keberhasilan dan keberlanjutan pembangunan di masa depan karena dapat menyerap tenaga kerja, sehingga dapat membuka kesempatan kerja baru bagi masyarakat yang pada gilirannya akan berdampak terhadap peningkatan pendapatan masyarakat.

Pertumbuhanekonomi memang penting, strategi penanggulangan kemiskinan yang lebih lengkap harus mengambilfaktor yang relevan, dalam konteks desentralisasi, analisis subnasionaldapat menjadi pendekatan instruktif untuk memeriksa pemerintahan lokal dalam kaitannya denganpertumbuhan dan pengentasan kemiskinan (Balisacan,2003). Pertumbuhan ekonomi, akan membuka lapangan kerja, menyerap angkatan kerja, yang pada akhirnya akan mengurangi kemiskinan penduduk. Manusia yang berkualitas tinggi dan menguasai teknologi dapat menghasilkan nilai tambah dan mendorong pertumbuhan ekonomi (Seran,2017). Kebutuhan tenaga kerja juga akan memperluas kesempatan kerja serta berdampak terhadap naiknya penghasilan masyarakat sehingga kesejahteraan masyarakatpun meningkat, jika pertumbuhan ekonomi tinggi akan mengakibatkan aktivitas ekonomi dan semakin terbukanya kesempatan kerja. Kondisi semacam ini akan membawa konsekuensi logis terhadap terciptanya faktor penarik bagi penduduk daerah yang pertumbuhan dan tingkat pendapatan yang lebih rendah untuk mencari pekerjaan di daerah yang tingkat pendapatannya lebih tinggi (Suartha,2017). Pertumbuhan ekonomi merupakan proses kenaikan output per kapita dalam jangka panjang ini mengandung tiga hal pokok yaitu proses, output per kapita dan jangka panjang. Proses menunjukkan bahwa perkembangan ekonomi dari waktu ke waktu akan terus mengalami perubahan, dalam pembangunan ekonomi tingkat pendapatan per kapita terus-menerus meningkat, sedangkan kenaikan pertumbuhan ekonomi belum tentu diikuti oleh kenaikan pendapatan per kapita (Adipuryanti Y,2015).

Dilihat dari Gambar 1 menunjukan bahwa pertumbuhan ekonomi dan IPM pada tahun 2013-2016 mengalami kenaikan. Kesejahteraan masyarakat merupakan tujuan dari pembangunan, kesejahteraan masyarakat dapat dilihat dari meningkatnya pertumbuhan ekonomi dan meratanya distribusi pendapatan. Penentuan kebijakan-kebijakan dalam proses pembangunan pada dasarnya bertujuan untuk mencapai suatu kesejahteraan yang adil dan makmur dalam masyarakat (Artana Y,2015). Kesejahteraan masyarakat menunjukkan ukuran hasil pembangunan masyarakat dalam mencapai kehidupan yang lebih baik yang meliputi: pertama, peningkatan kemampuan dan pemerataan distribusi kebutuhan dasar seperti makanan, perumahan, kesehatan, dan perlindungan kedua, peningkatan tingkat kehidupan, tingkat pendapatan, pendidikan yang lebih baik, dan peningkatan atensi terhadap budaya dan nilai-nilai kemanusiaan dan ketiga, memperluas skala ekonomi dan ketersediaan pilihan sosial dari individu dan bangsa. Kesejahteraan memiliki banyak dimensi, yakni dapat dilihat dari dimensi materi dan dimensi non materi. Dari sisi materi dapat diukur dengan pendekatan pendapatan dan konsumsi (Hukom,2014).

Dalam menciptakan kesempatan kerja atau lapangan kerja tersebut dalam rangka pembangunan ekonomi terutama untuk penyerapan tenaga kerja maka lebih baik diarahkan pada pembangunan industri khususnya padat karya, tetapi juga mengarah pada peningkatan investasi ke sektor-sektor yang padat karya sehingga dengan dana investasi terbatas dapat melaksanakan penciptaan lapangan kerja produktif (Taufik,2014). Meningkatkan PDRB dan laju pertumbuhan 


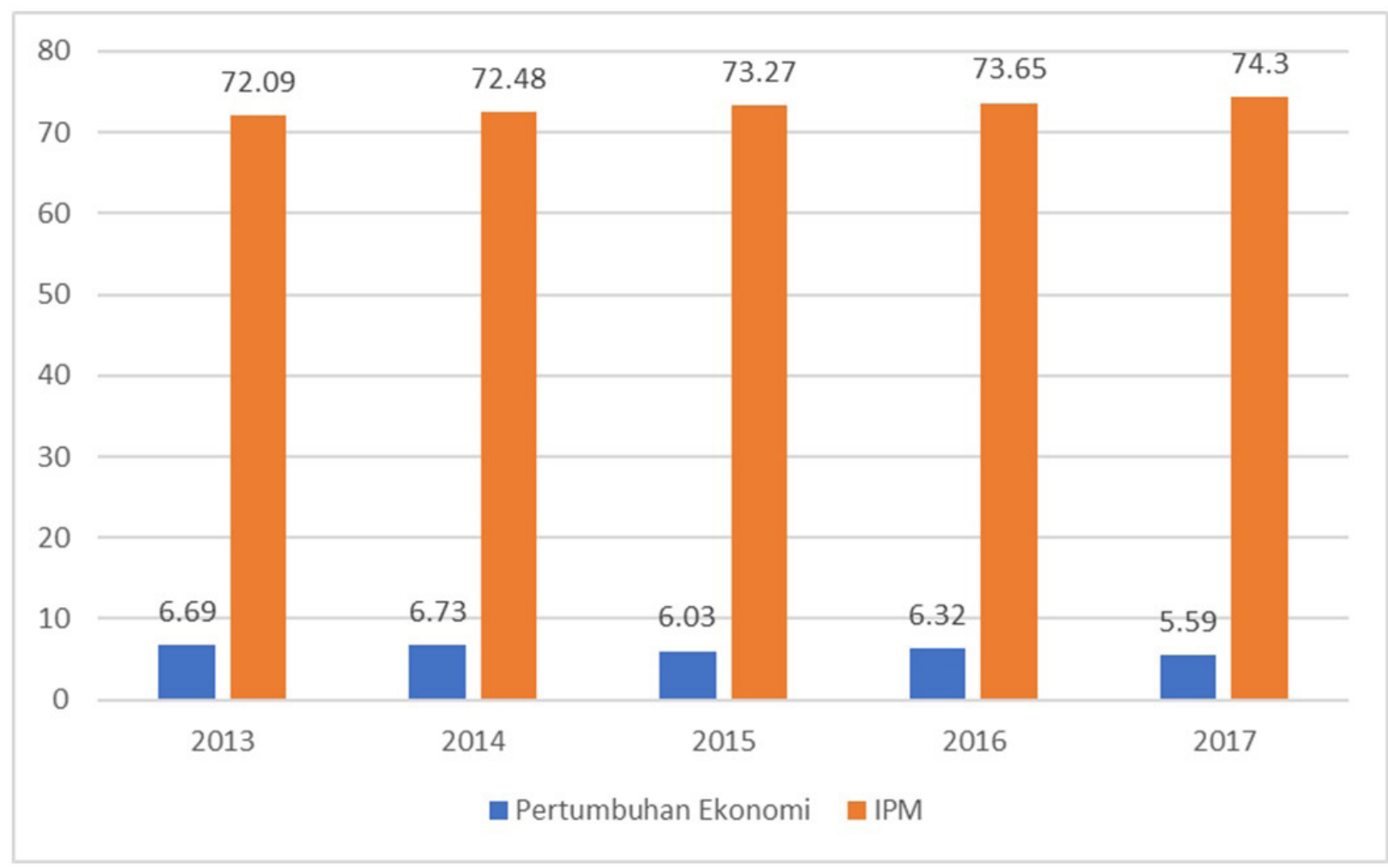

\section{Grafik Perbandingan Pertumbuhan Ekonomi dan Indeks Pembangunan Manusia Menurut Kabupaten/Kota Provinsi Bali Tahun 2013-2017}

ekonomi daerah juga perlu memperhatikan pembangunan manusia. Tingkat pembangunan manusia dapat mempengaruhi kemampuan penduduk dalam mengelola berbagai sumber daya untuk mendorong pertumbuhan ekonomi. Ukuran perkembangan pembangunan manusia menggunakan indikator komposit yaitu IPM, yang tersusun atas indeks kesehatan, indeks pendidikan, dan indeks standar hidup layak. Tujuan pembangunan manusia yang tercermin pada Indeks Pembangunan Manusia (IPM) sangat tergantung pada pemerintah sebagai penyedia sarana penunjang. IPM tidak dapat berdiri sendiri dan saling membutuhkan satu dengan yang lainnya. Peran pemerintah sebagai penyusun kebijakan sangat dibutuhkan untuk memberi kesempatan bagi seluruh lapisan masyarakat guna memperbaiki kualitas hidup melalui keterlibatan masyarakat dalam pembangunan.

Dalam penelitian Suciati (2015) menyebutkan bahwa, IPM adalah salah satu indikator tingkat kesejahteraan masyarakat di suatu wilayah, penelitian ini digunakan
IPM sebagai acuan untuk menentukan tingkat kesejahteraan dalam bentuk rangking kesejahteraan suatu daerah. Informasi tentang perkembangan kesejahteraan masyarakat merupakan suatu masukan yang penting dalam proses perencanaan pembangunan. Pemerintah dapat meningkatkan kesejahteraan masyarakat melalui peningkatan pembangunan manusia yang tercermin dari IPM yang meningkat yang terjadi di kabupaten/kota provinsi Bali.

Berdasarkan hasil penelitian yang dilakukanolehRetno(2015)menunjukan variabel pengeluaran pemerintah berpengaruh signifikan positif terhadap penyerapan tenaga kerja terdidik serta penyerapan tenaga kerja tidak terdidik dan tidak terlatih. Pengaruh positif dari pengeluaran pemerintah begitu dirasakan oleh tenaga kerja tidak terdidik dan tidak terlatih. Choi (2007) mengadakan penelitian pengaruh pertumbuhan ekonomi terhadap penciptaan kesempatan kerja. Hasil penelitiannya adalah ada hubungan yang signifikan antara pertumbuhan ekonomi dengan penciptaan kesempatan kerja bagi para penganggur. Seyfriend (2011) menyimpulkan 
ada hubungan signifikan antara pertumbuhan ekonomi dengan penyerapan tenaga kerja pada sepuluh negara bagian di Amerika Serikat

Menurut Mirza (2012) semakin meningkatnya pertumbuhan ekonomi maka semakin tinggi pertumbuhan output perkapita dan meningkatnya daya beli masyarakat. Tingginya daya beli masyarakat akan meningkatkan kesejahteraan karena daya beli masyarakat merupakan salah satu indikator komposit dalam IPM yang disebut indikator pendapatan.Pertumbuhan ekonomi berpengaruh tidak berpengaruh positif dan signifikan terhadap kesejahteraan masyarakat. Tanda positif bermakna bahwa kenaikan pada laju pertumbuhan ekonomi akan disertai dengan kenaikan kesejahteraan masyarakat di provinsi di Indonesia (Sulistiawati, 2012).

Menurut Nurrohman (2010) Adapun hubungan kausalitas yang terjadi antara pertumbuhan ekonomi dengan penyerapan tenaga kerja , dari hasil uji granger dihasilkan bahwa hubungan antara keduanya bersifat satu arah yaitu bahwa penyerapan tenaga kerja mempengaruhi pertumbuhan ekonomi. Penelitian Ramirez (1998) menyebutkan bahwa terdapat hubungan positif antara pertumbuhan ekonomi dengan indeks pembangunan manusia sebagai ukuran dari kesejahteraan masyarakat. Denni (2012) dalam penelitian yang berjuadul Pengaruh kemiskinan, pertumbuhan ekonomi dan belanja modal terhadap indeks pembangunan manusia kabupaten jawa tengah menunjukan hasil bahwa pertumbuhan ekonomi berpengaruh positif dan signifikan terhadap IPM sebagai ukuran kesejahteraan masyarakat. Pertumbuhan yang tinggi akan meningkatkan pendapatan penduduk dan seterusnya taraf hidup, akhirnya menjamin kemakmuran masyarakat, meningkatkan tahap kesehatan, keharmonian serta kesejahteraan yng berkelanjutan yang akan dapat melangsungkan pertumbuhan ekonomi.

Kesejahteraan masyarakat diharapkan akan terwujud apabila pertumbuhan ekonomi yang terus meningkat akan menciptakan lapangan kerja sehinggga dapat menyerap tenaga kerja lebih banyak pada tingkat upah yang layak (Dwirainaningsih,2017). Pada penelitian Wijayanti dan Darsana (2015) menyatakan bahwa adanya hubungan yang positif dan signifikan antara variable pertumbuhan ekonomi dan kesejahterahan masyarakat di kabupaten/ kota Provinsi Bali.Islam (2004) menyimpulkan pertumbuhan ekonomi yang tinggi di negara Indonesia di tahun 1970-an dan 1980-an mampu diikuti oleh meningkatnya penyerapan tenaga kerja (menurunnya pengangguran) dan mengurangi kemiskinan yang ada. Berbeda dengan negara Ethopia, dimana pertumbuhan yang moderate tahun 1990-an tidak memberikan pengaruh signifikan terhadap pengurangan kemiskinan serta tidak diiringi oleh adanya penyerapan tenaga kerja yang baru dikalangan pengangguran.

Todaro (2009) mendefinisikan pembangunan ekonomi sebagai suatu proses multidimensional yang mencakup perubahan struktur, sikap hidup dan kelembagaan. selain itu juga pembangunan ekonomi mencakup peningkatan pertumbuhan ekonomi, pengurangan tidak merataan distribusi pendapatan dan pemberantas kemiskinan, demi menghasilkan kemajuan ekonomi yang benarbenar bermanfaat dan melalui proses yang efisien. Sukirno (2006) mengartikan bahwa pembangunan ekonomi adalah pertumbuhan ekonomi yang diikuti oleh perubahan aspek lain yang meliputi serangkaian usaha dalam suatu perekonomian untuk mengembangkan kegiatan ekonomi sehingga infrastruktur lebih banyak tersedia, perusahaan semakin berkembang, taraf pendidikan semakin tinggi dan teknologi semakin meningkat sebagai implikasi dari perkembangan ini diharapkan kesempatan kerja akan bertambah, tingkat endapatan meningkat dan kemakmuran masyarakat menjadi semakin tinggi. Hal ini berarti pembangunan ekonomi sebagai proses yang menyebabkan pendapatan perkapita suatu masyarakat mengalami kenaikan secara berkepanjangan. Menurut Arsyad (2010) pembangunan ekonomi daerah adalah suatu proses dimana pemerintah daerah dan masyarakat mengelola setiap sumber daya yang ada dan membentuk suatu pola antara pemerintah daerah dengan sektor swasta untuk menciptakan suatu lapangan kerja baru.

Teori pertumbuhan ekonomi merupakan salah satu landasan menentukan perkembangan pertumbuhan ekonomi. Pertumbuhan ekonomi berdampak langsung terhadap peningkatan dan pemerataan pendapatan masyarakat dan semakin berkurangnya jumlah penduduk miskin (Patera,2015). Pertumbuhan ekonomi suatu daerah adalah peningkatan hasil kegiatan 
ekonomi seluruh unit ekonomi dalam suatu wilayah, pada umumnya dikenal dengan terjadinya peningkatan PDRB. Keberhasilan pembangunan pada suatu daerah dapat dilihat dari pertumbuhan ekonominya yang menggambarkan suatu dampak dari kebijakan pembangunan yang dilaksanakan. Pertumbuhan ekonomi menerangkan atau mengukur prestasi dari perkembangan sesuatu ekonomi. (Odhiambo, 2009).

Menurut pandangan ahli ekonomi klasik terdapat empat fakor yang mempengaruhi pertumbuhan ekonomi, yaitu: jumlah penduduk,jumlah stok barang-barang modal, luas tanah dan kekayaan alam serta tingkat teknologi yang digunakan. Menurut pandangan ahli ekonomi klasik hukum hasil tambahan yang semakin berkurang mempengaruhi pertumbuhan ekonomi. Ini berarti pertumbuhan ekonomi tidak akan terus menerus berlangsung. Pada awalnya, apabila penduduk sedikit dan kekayaan alam relatif berlebihan, tingkat pengembalian modal dari investasi yang dibuat adalah tinggi, maka para pengusaha akan mendapatkan keuntungan yang besar. Ini akan menimbulkan investasi baru dan pertumbuhan ekonomi terwujud. Keadaan seperti itu tidak akan terus menerus berlangsung. Apabila penduduk sudah terlalu banyak, pertambahannya akan menurunkan tingkat kegiatan ekonomi karena produktivitas setiap penduduk telah menjadi negatif. Maka kemakmuran masyarakat akan menurun kembali. Dari uraian tersebut dilihat bahwa apabila terdapat kekurangan penduduk, produksi marjinal lebih tinggi daripada pendapatan per kapita. Maka pertambahan penduduk akan menaikkan pendapatan per kapita. Akan tetapi apabila penduduk sudah semakin banyak, hukum hasil tambahan yang semakin berkurang akan mempengaruhi fungsi produksi, yaitu produksi marjinal akan mengalami penurunan (Sukirno, 2012:433).

Teori pertumbuhan Neo Klasik dilihat dari sudut pandangan yang berbeda, yaitu dari segi penawaran. Menurut teori ini yang dikembangkan oleh Abhamovits dan solow, pertumbuhan ekonomi tergantung kepada perkembangan faktor - faktor produksi. Teori pertumbuhan Solow-Swan telah dikategorikan sebagai teori pertumbuhan neo klasik.

Penduduk yang tersebar di berbagai sektor perekonomian, sektor yang mempekerjakan banyak orang umumnya menghasilkan barang dan jasa yang relatif besar. Setiap sektor mengalami laju pertumbuhan yang berbeda, demikian pula dengan kemampuan setiap sektor dalam penyerapan tenaga kerja perbedaan laju pertumbuhan tersebut mengakibatkan dua hal. Pertama, terdapat perbedaan laju peningkatan produktivitas kerja di masing-masing sektor. Kedua, secara berangsur-angsur terjadi perubahan sektoral, baik dalam penyerapan tenaga kerja maupun dalam kontribusinya dalam pendaatan nasional (Simanjuntak,Payaman, 1990).

Penyerapan tenaga kerja bisa diartikan dengan keseimbangan interaksi antara permintaan tenaga kerja dan penawaran tenaga kerja, yang dimana permintaan tenaga kerja pasar dan penawaran tenaga kerja pasar secara bersama menentukan suatu tingkat upah keseimbangan dan suatu penggunaan tenaga kerja keseimbangan. Banyak tenaga kerja yang tersedia tetapi tidak dapat diserap oleh industri hal ini dikarenakan keahlian tenaga kerja tidak sesuai dengan yang dibutuhkan oleh industri di sinilah perlunya peranan pemerintah untuk melakukan pendidikan atau pelatihan terhadap tenaga kerja agar memiliki skill yang dibutuhkan oleh industri. Mengingat kesempatan kerja yang terbatas tersebut maka pemerintah mengupayakan menciptaan lapangan kerja yang nantinya dapat menampung maupun mengurangi tingkat pengangguran yang berada di tengah masyarakat melalui penciptaan usaha usaha industri kecil.

Semakin bertambahnya jumlah industri kecil akan membawa dampak sangat luas terhadap penyerapan tenaga kerja, peningkatan SDM yang terbatas tentunya akan menghambat pengembangan itu sendiri, merupakan tugas dan tanggung jawab masyarakat secara bersama sama dengan pemerintah untuk menciptakan lapangan pekerjaan serta berpartisipasi menunjang program pemerintah pada peningkatan taraf hidup yang lebih adil dan merata, lalu pemerintah memberikan bantuan dan penyuluhan.

Penyerapan tenaga kerja sebagai jumlah tertentu dari tenaga kerja yang digunakan dalam suatu unit usaha tertentu atau dengan kata lain penyerapan tenaga kerja adalah jumlah tenaga kerja yang bekerja dalam suatu unit usaha. Terjadinya penyerapan tenaga 
kerja disebabkan oleh adanya permintaan akan tenaga kerja oleh karena itu, penyerapan tenaga kerja dapat dikatakan sebagai permintaan tenaga kerja.

Pengeluaran pemerintah versi Keynes, pengeluaran pemerintah merupakan salah satu unsur permintaan agregat. Konsep perhitungan pendapatan nasional dengan pendekatan bahwa $\mathrm{Y}=\mathrm{C}+\mathrm{I}+\mathrm{G}+\mathrm{X}-\mathrm{M}$. Formula ini dikenal sebagai identitas pendapatan nasioanl. Variabel Y melambangkan pendapatan nasional sekaligus mencerminkan penawaran agregat. Sedangkan variabel-variabel di ruas kanan disebut permintaan agregat. Variabel $\mathrm{G}$ melambangkan pengeluaran pemerintah, dengan membandingkan nilai $G$ terhadap $Y$ serta mengamati dari waktu ke waktu dapat diketahui seberapa besar kontribusi pengeluaran pemerintah dalam pembentukan pendapatan nasional (Dumairy, 1996). Pengeluaran pemerintah (Government pourchase) meliputi pengeluaran untuk barang dan jasa yang dilakukan oleh pemerintah. Pengeluaran pemerintah mencakup upah pegawai negeri dan pengeluaran untuk pekerjaan umum (Mankiw, 2013) .

Pengeluaran pemerintah adalah bagian dari kebijakan fiskal yaitu suatu tindakan pemerintah untuk mengatur jalannya perekonomian dengan cara menentukan besarnya penerimaan dan pengeluaran pemerintah setiap tahunnya, yang tercermin dalam dokumen Anggaran Pendapatan Belanja Negara (APBN) untuk nasional dan Anggaran Pendapatan Belanja Daerah (APBD) untuk daerah atau regional Pengeluaran pemerintah adalah bagian dari kebijakan fiskal (Sukirno,2006), yaitu kebijakan pemerintah dalam bidang pengeluaran dan pendapatan dengan tujuan untuk menciptakan tingkat kesempatan kerja yang tinggi.

Kebijakan fiskal dalam rangka menstabilkan harga, tingkat output, maupun kesempatan kerja dan mampu mendorong pertumbuhan ekonomi. Menurut Keynes bahwa peranan atau campur tangan pemerintah masih sangat diperlukan apabila perekonomian sepenuhnya diatur oleh kegiatan di pasar bebas. Tujuan dari teori mikro mengenai pengeluaran pemerintah adalah untuk menganalisis faktorfaktor yang menimbulkan permintaan akan barang pemerintah (barang yang disediakan oleh pemerintah) dan menganalisis pengaruh faktor- faktor tersebut atas tersedianya barang pemerintah. Interaksi antara permintaan dan penawaran untukbarang pemerintah menentukan jumlah barang pemerintah yang akan disediakan melalui anggaran belanja. Jadi pengeluaran pemerintah dapat dijelaskan dengan beberapa faktor yaitu: perubahan permintaan akan barang publik, perubahan dari aktivitas pemerintah dalam menghasilkan barang publik, dan juga perubahan dari kombinasi faktor produksi yang digunakan dalam proses produksi.

Soetrisno (1981:339) menjelaskan klasifikasi pengeluaran pemerintah yang digunakan baik pemerintah pusat maupun daerah terdiri dari dua pengeluaran yaitu: 1 . Pengeluaran/belanja rutin adalah belanja untuk pemeliharaan atau penyelenggaraan pemerintah sehari-hari. Pengeluaran rutin ini merupakan perkembangan istilah yang bersumber pada ICW (Indischi Comptabiliteit Wet Staatsblad 1923 nomor 448), belanja rutin ini terdiri dari belanja pegawai, belanja barang, belanja pemeliharaan dan belanja perjalanan. 2. Belanja pembangunan adalah pengeluaran untuk pembangunan baik pembangunan fisik seperti jalan, jembatan, gedung, maupun pembangunan non fisik spiritual termasuk penataran, training.

Kesejahterahan merupakan tujuan utama dari pelaksanaan pembangunan kesejahteraan sosial adalah suatu kondisi kehidupan yang baik, terpenuhi kebutuhan materi untuk hidup, kebutuhan spiritual, kebutuhan sosial seperti terjadinya sesuatu tatanan yang teratur, dapat mengelola konflik dalam kehidupan keseharian, terjamin dari segi keamanan, dan setiap orang memiliki kedudukan yang sama didepan hukum (keadilan terjamin) terjaganya kesenjangan sosial ekonomi. United Nations Development Programe (UNDP) mulai tahun 1990 telah menyusun suatu indikator kesejahteraan manusia yang dapat menunjukan kemajuan manusia berdasarkan faktor-faktor, seperti ratarata usia harapan hidup, rata-rata lama sekolah, angka melek huruf, dan kesejahteraan secara keseluruhan.

Laporan ini menganggap bahwa pembangunan manusia pada hakekatnya adalah suatu proses memperbesar pilihan-pilihan manusia. Indikator kesejahterahan masyarakat yang disusun oleh UNDP dikenal dengan Human Development Index (HDI) atau Indeks Pembangunan Manusia (IPM). Human Developmeny Index (HDI) 
merupakan perangkat yang sangat bermanfaat untuk mrngukur tingkat kesejahterahan antar negara maupun daerah. Adapun metode perhitungan Indeks Pembangunan Manusia (IPM) yang terdiri dari tiga komponen yaitu lamanya hidup diukur dengan harapan hidup saat lahir, tingkat pendidikan diukur dengan kombinasi antar angka melek huruf pada penduduk dewasa (dengan bobot dua per tiga) dan rata-rata lama sekolah (dengan bobot sepertiga), dan kehidupan yang layak diukur dengan pengeluaran perkapita yang telah disesuaikan (Susanto dan Rachmawati, 2013).

Negara yang menerapkan kebijakan sosial atau kebijakan kesejahteraan yang menjamin warganya dengan berbagai pelayanan dan skema jaminan sosial yang meratadikarenakan manfaat pajak sering tidak sampai kepada masyarakat. Konsep kesejahteraan masyarakat memandang manusia tidak hanya sebagai individu, akan tetapi juga sebagai anggota atau warga dari kolektiva dan bahwa manusia bukanlah semata-mata merupakan alat kepentingan kolektiva, akan tetapi juga untuk kepentingan dirinya sendiri. Konsep dan teori kesejahteraan masyarakat bahwa negara harus secara aktif mengupayakan kesejahteraan, bertindak adil yang dapat dirasakan oleh seluruh lapisan masyarakat secara merata dan seimbang, bukan mensejahterakan golongan tertentu saja tetapi seluruh lapisan masyarakat yang ada di Indonesia. Kesejahteraan masyarakat merupakan tujuan dan upaya yang dilakukan pemerintah melalui upaya-upaya seperti peningkatan pertumbuhan ekonomi (Edogbanya et al, 2013). Menurut Akudugu (2012), menyatakan bahwa pembangunan sosial ekonomi yang mencerminkan kesejahteraan masyarakat diharapkan dapat terwujud melalui upaya yang dilakukan oleh pemerintah. Kesejahteraan masyarakat dapat dilihat melalui perkembangan pertumbuhan ekonomi dan meratanya distribusi pendapatan. Menurut Kaur (2016), pertumbuhan ekonomi juga dipengaruhi oleh teknologi dan pengetahuan. investasi dalam pendidikan dan kesehatan dianggap sebagai cara yang paling efektif. investasi dalam pendidikan dan kesehatan dianggap sebagai cara yang paling efektif meningkatkan pendapatan provinsi dan mengurangi kesenjangan dalam PDB provinsi perkapita di Indonesia (Garcia dan Soelistianingsih 1998).

\section{METODE PENELITIAN}

Penelitian ini dilakukan di Kabupaten/ kota Provinsi Bali. Lokasi ini dipilih karena dirasakannya masih perlu ada upaya untuk meningkatkan kesejahteraan masyarakat, dengan melihat dari segi pertumbuhan ekonomi, pengeluaran pemerintah dan penyerapan tenaga kerja agar seluruh lapisan masyarakat di Provinsi Bali dapat merasakan kesejahteraan secara merata.

Metode analisis jalur (path analisys). Analisis jalur merupakan perluasan dari analisis regresi linier berganda, untuk menaksir hubungan kaustalitas antar variabel model (model casual) yang berjenjang berdasarkan teori. Analisis yang digunakan untuk mengetahui hubungan langsung variabel independen terhadap variabel dependen dan hubungan yang tidak langsung melalui variabel mediasi.

Persamaan Struktural I

$\mathrm{Y}_{1}=\mathrm{b}_{1} \mathrm{X}_{1}+\mathrm{b}_{2} \mathrm{X}_{2}+\mathrm{e}_{1}$

Persamaan Struktural II

$\mathrm{Y}_{2}=\mathrm{b}_{3} \mathrm{X}_{1}+\mathrm{b}_{4} \mathrm{X}_{2}+\mathrm{b}_{5} \mathrm{Y}_{1}+\mathrm{e}_{2}$

Keterangan :

$\mathrm{X}_{1}=$ Pertumbuhan ekonomi

$\mathrm{X}_{2}=$ pengeluaran pemerintah

$\mathrm{Y}_{1=}^{2}$ Penyerapan tenaga kerja

$\mathrm{Y}_{2}=$ Kesejahteraan masyarakat

$\mathrm{e}_{1} \mathrm{e}_{2}=$ Nilai kekeliruan taksiran standar

$\mathrm{b}_{1}, \mathrm{~b}_{5}=$ Koefisien jalur masing-masing variabel

Nilai kekeliruan taksiran standard (standard error of estimate), yaitu:

$e e_{1=\sqrt{1-R_{i}^{2}}} \sqrt{1-R_{i}^{2}}$

Anak panah $e_{2}$ variabel penyerapan tenaga kerja $\left(\mathrm{Y}_{2}\right)$ yang tidak dapat dijelaskan oleh pertumbuhan ekonomi $\left(\mathrm{X}_{1}\right)$ dan pengeluaran pemerintah $\left(\mathrm{X}_{2}\right)$. Nilai kekeliruan taksiran standar (standard error of estimate) yaitu:

$e e_{2} \sqrt{1-R_{i}^{2}} \sqrt{1-R_{i}^{2}}$

Total keragantan data yang dapat dijelaskan oleh model diukur dengan :

$R_{m}^{2} R_{m=1}^{2} 1-\left(e_{1}^{2} e_{1}^{2} e_{1}^{2} e_{1}^{2} \ldots e_{p}^{2} e_{p}^{2}\right)$

\section{HASIL DAN PEMBAHASAN}

Perhitungan koefisien path dilakukan dengan menggunakan software SPSS 18.0 for Windows,berdasarkan hasil olah data maka persamaan struktural 1, maka dapat dibuat 
persamaan sebagai berikut:

$$
\hat{Y}_{1} \hat{Y}_{1}=0,011 \mathrm{X}_{1}+0,741 \mathrm{X}_{2}
$$

Variabel pertumbuhan ekonomi dengan

nilai $\frac{\text { sigsig }}{2}, 0,459>0,050$ menunjukan bahwa pertumbuhhan ekonomi tidak berpengaruhpositif dan signifikan terhadap penyerapan tenaga kerja.

Pengeluaran pemerintah dengan nilai $\frac{\text { sigsig }}{22}$, $0,000<0,050$ menunjukan bahwa pengeluaran pemerintah berpengaruh positif dan signifikan terhadap penyerapan tenaga kerja.

Perhitungan koefisien path dilakukan dengan menggunakan software SPSS 18.0 for Windows,Berdasarkan hasil olah data persamaan struktural 2 sebagai berikut:

$$
\widehat{Y}_{2} \hat{Y}_{2}=0,161 \mathrm{X}_{1}+0,371 \mathrm{X}_{2}+0,387 \mathrm{Y}_{1}
$$
Variabel pertumbuhan ekonomi dengan $\underline{\text { sigsig }}$

nilai $\frac{22}{2}, 0,067>0,050$ menunjukan bahwa pertumbuhan ekonomi berpengaruh positif dan tidak signifikan terhadap kesejahteraan masyarakat. Pengeluaran pemerintah dengan nilai sig. $0,011<0,050$ menunjukan bahwa pengeluaran pemerintah berpengaruh positif dan signifikan terhadap kesejahteraan masyarakat. Penyerapan tenaga kerja dengan nilai sig. 0,008 $<0,050$ menunjukan bahwa penyerapan tenaga kerja bengaruh positif dan signifikan terhadap kesejahteraan masyarakat.

vUntuk mengetahui nilai el yang menunjukan jumlah variabel penyerapan tenaga kerja (Y1) yang tidak di jelaskan oleh pertumbuhan ekonomi (X1) dan pengeluaran pemerintah (Y2) dengan menggunakan rumus:

$$
\begin{aligned}
\mathrm{e}_{\mathrm{i}} & =\sqrt{1-\mathrm{R}_{\mathrm{i}}^{2}} \sqrt{1-\mathrm{R}_{\mathrm{i}}{ }^{2}} \\
\mathrm{e}_{1} & =\sqrt{1-550^{2}} \sqrt{1-550^{2}} \\
& =0,697
\end{aligned}
$$

Untuk mengetahui nilai $e_{2}$ yang menunjukan jumlah variabel kesejahteraan masyarakat $\left(\mathrm{Y}_{2}\right)$ yang tidak dijelaskan oleh pertumbuhan ekonomi $\left(\mathrm{X}_{1}\right)$, pengeluaran pemerintah $\left(\mathrm{X}_{2}\right)$, dengan menggunakan rumus:

$$
\begin{aligned}
\mathrm{e}_{\mathrm{i}} & =\sqrt{1-\mathrm{R}_{\mathrm{i}}^{2}} \sqrt{1-\mathrm{R}_{\mathrm{i}}{ }^{2}} \\
\mathrm{e}_{1} & =\sqrt{1-550^{2}} \sqrt{1-550^{2}} \\
& =0,697
\end{aligned}
$$

Agar dapat mengetahui validitas model, terdapat indikator untuk melakukan pemeriksaan, yaitu koefisien determinasi total dengan hasil sebagai berikut:

$$
\begin{aligned}
& \mathrm{R}_{\mathrm{m}}^{2} \quad=1-\left(\mathrm{e}_{1}\right)^{2}\left(\mathrm{e}_{2}\right)^{2} \\
& =1-(0,697)^{2}(0,697)^{2} \\
& =1-(0,485)(0,485) \\
& =1-0,235 \\
& =0,765
\end{aligned}
$$

Keterangan :

$\mathrm{R}^{2} \mathrm{~m}=$ Koefisien determinasi total $\mathrm{e}_{1}, \mathrm{e}_{2}=$ Nilai kekeliruan taksiran standar Berdasarkan hasil perhitungan koefisien determinasi total, maka diperoleh bahwa keragaman data yang dapat dijelaskan oleh model adalah sebesar 76 persen atau dengan kata lain informasi yang terkandung dalam data sebesar 76 persen dapat dijelaskan oleh model, sedangkan sisanya 24 persen dijelaskan oleh variabel lain yang tidak terdapat dalam model.

Berdasarkan perhitungan mengunakan SPSS diperoleh nilai Standardized coefficient beta sebesar 0,011 dan nilai signifikan sebesar 0,459 . Berdasarkan hasil nilai standardized coefficient beta sebesar 0,011 dan nilai signifikan sebesar 0,459. Berarti pertumbuhan ekonomi $\left(\mathrm{X}_{1}\right)$ tidak berpengaruh positif terhadap penyerapan tenaga kerja $\left(\mathrm{Y}_{1}\right)$.

Berdasarkan perhitungan mengunakan SPSS diperoleh nilai Standardized coefficient beta sebesar 0,741 dan nilai signifikan sebesar 0,000 . Berdasarkan perhitungan mengunakan SPSS diperoleh nilai Standardized coefficient beta sebesar 0,741 dan nilai signifikan sebesar 0,000 . Berarti pengeluaran pemerintah $\left(\mathrm{X}_{2}\right)$ berpengaruh positif terhadap penyerapan tenaga $\operatorname{kerja}\left(\mathrm{Y}_{1}\right)$.

Berdasarkan perhitungan mengunakan SPSS diperoleh nilai Standardized coefficient beta sebesar 0,161 dan nilai signifikan sebesar 0,067 . Berdasarkan perhitungan mengunakan SPSS diperoleh nilai Standardized coefficient beta sebesar 0,161 dan nilai signifikan sebesar 0,134. Berarti Pertumbuhan ekonomi $\left(X_{1}\right)$ tidak berpengaruh positif terhadap kesejahteraan masyarakat $\left(\mathrm{Y}_{2}\right)$.

Berdasarkan perhitungan mengunakan SPSS diperoleh nilai Standardized coefficient beta sebesar 0,371 dan nilai signifikan sebesar 0,022 . Berdasarkan perhitungan mengunakan SPSS diperoleh nilai Standardized coefficient beta sebesar 0,371 dan nilai signifikan sebesar 0,011. Berarti Pengeluaran pemerintah $\left(\mathrm{X}_{2}\right)$ berpengaruh positif terhadap kesejahteraan 
masyarakat $\left(\mathrm{Y}_{2}\right)$.

Berdasarkan perhitungan mengunakan SPSS diperoleh nilai Standardized coefficient beta sebesar 0,378 dan nilai signifikan sebesar 0,008 . Berdasarkan perhitungan mengunakan SPSS diperoleh nilai Standardized coefficient beta sebesar 0,378 dan nilai signifikan sebesar 0,017 . Berarti Pengeluaran pemerintah $\left(X_{2}\right)$ berpengaruh positif terhadap kesejahteraan masyarakat $\left(\mathrm{Y}_{2}\right)$.

Jika $Z$ hitung $>-1,96 \leq Z$ hit $\leq+1,96$, maka $\mathrm{H}_{0}$ diterima, berarti pertumbuhan ekonomi bukan merupakan variabel mediasi terhadap kesejahteraan masyarakat.

Jika $\mathrm{Z}$ hitung $>+1,96$ atau $\mathrm{Z}$ hit $<-$ 1,96, maka $\mathrm{H}_{0}$ ditolak , berarti pertumbuhan ekonomimerupakan variabel mediasi terhadap kesejahteraan masyarakat.

$$
\begin{aligned}
& S_{b 1 b 5}=\sqrt{b 5^{2} S_{b 1}^{2}+b 1^{2} S_{b 5}^{2}} \\
& S_{b 1 b 5} S_{b 1 b 5}= \\
& \sqrt{(4,559)^{2}(0,047)^{2}+(0,005)^{2}(1,838)^{2}} \\
& \sqrt{(4,559)^{2}(0,047)^{2}+(0,005)^{2}(1,838)^{2}} \\
& S_{b 1 b 5} S_{b 1 b 5}=0,01015
\end{aligned}
$$

\section{Keterangan:}

Sb1b5= besarnya standard error tidak langsung

Sb1 = standar error koefisien b1

b1 = jalur X1 terhadap Y1

$\mathrm{Sb} 5=$ standar error koefisien b5

$\mathrm{b} 5=$ jalurY1 terhadap Y2

$\mathrm{b} 1 \mathrm{~b} 5=$ jalur $\mathrm{X} 1$ terhadap $\mathrm{Y} 1\left(\mathrm{~b}_{1}\right)$ dengan jalur $\mathrm{Y} 1$ terhadap $\mathrm{Y} 2\left(\mathrm{~b}_{5}\right)$.

Untuk menguji signifikansi pengaruh tidak langsung maka menghitung $\mathrm{Z}$ dari koefisien $\mathrm{b}_{1} \mathrm{~b}_{5}$ dengan rumus sebagai berikut:

$$
\begin{aligned}
& \mathrm{Z}=\frac{b 1 b 5 b 1 b 5}{S b 1 b 5 S b 1 b 5} \\
& \mathrm{Z}=\frac{(0,005)(4,559)(0,005)(4,559)}{\mathrm{Z}=2,245^{01015}} \\
& \mathrm{O}, 01015
\end{aligned}
$$

Secara absolut $Z$ hitung sebesar $2,245>1,96$, artinya penyerapan tenaga kerja sebagai variabel mediasi pada pertumbuhan ekonomi di kabupaten/kota provinsi Bali.

Jika Z hitung $>-1,96 \leq$ Zhit $\leq+$
1,96, maka $\mathrm{H}_{0}$ diterima, berarti pengeluaran pemerintah bukan merupakan variabel mediasi terhadap kesejahteraan masyarakat.

Jika Z hitung $>+1,96$ atau Zhit $<$ 1,96 maka $\mathrm{H}_{0}$ ditolak, berarti pengeluaran pemerintah merupakan variabel mediasi terhadap kesejahteraan masyarakat.

$$
\begin{aligned}
& S_{b 2 b 5}=\sqrt{b 5^{2} S_{b 2}^{2}+b 2^{2} S_{b 5}^{2}} \\
& S_{b 2 b 5} S_{b 2 b 5}= \\
& \sqrt{(4,559)^{2}(0,103)^{2}+(0,735)^{2}(1,838)^{2}} \\
& \sqrt{(4,559)^{2}(0,103)^{2}+(0,735)^{2}(1,838)^{2}} \\
& S_{b 2 b 5} S_{b 2 b 5}=1,87337
\end{aligned}
$$

Keterangan :

$\mathrm{Sb} 2 \mathrm{~b} 5=$ besarnya standard error tidak langsung

$\mathrm{Sb} 2=$ standar error koefisien b2

$\mathrm{Sb} 5=$ standar error koefisien b5

$\mathrm{b} 2=$ jalur $\mathrm{X} 2$ terhadap $\mathrm{Y} 1$

$\mathrm{b} 5=$ jalurY1 terhadap $\mathrm{Y} 2$

b2b5 = jalur X2 terhadap $\mathrm{Y} 1\left(\mathrm{~b}_{2}\right)$ dengan jalur Y1 terhadap Y2 $\left(b_{5}\right)$.

Untuk menguji signifikansi pengaruh tidak langsung maka menghitung $\mathrm{z}$ dari koefisien $\mathrm{ab}$ dengan rumus sebagai berikut:

$$
\begin{aligned}
& \mathrm{Z}=\frac{b 2 b 5 \quad b 2 b 5}{S b 2 b 5 S b 2 b 5} \\
& \mathrm{Z}=\frac{(0,735)(4,559)(0,735)(4,559)}{\mathrm{Z}}=1,7886^{337} 1,87337
\end{aligned}
$$

Secara absolut $Z$ hitung sebesar 1,7886 $\leq$ 1,96 , artinya penyerapan tenaga kerja bukan sebagai variabel mediasi pada pengeluaran pemerintah di kabupaten/kota provinsi Bali.

Pertumbuhan ekonomi tidak berpengaruh positif terhadap penyerapan tenaga kerja. Pertumbuhan ekonomi berpengaruh tidak berpengaruh positif dan signifikan terhadap kesejahteraan masyarakat. Tanda positif bermakna bahwa kenaikan pada laju pertumbuhan ekonomi akan disertai dengan kenaikan kesejahteraan masyarakat di provinsi di Indonesia. Pertumbuhan ekonomi tidak berkualitas sehingga tidak membawa dampak pada peningkatan penyerapan tenaga kerja. Pada tataran nasional, rendahnya kualitas pertumbuhan ekonomi diindikasikan oleh 
Tabel 1.

Hasil Pengaruh Langsung, Pengaruh Tidak Langsung, dan Pengaruh Total Variabel Pertumbuhan Ekonomi, Pengeluaran Pemerintah, Penyerapan Tenaga Kerja dan Kesejahteraan Masyarakat di Kabupaten/Kota Provinsi Bali.

\begin{tabular}{lccc}
\hline $\begin{array}{c}\text { Hubungan } \\
\text { Variabel }\end{array}$ & Langsung & $\begin{array}{c}\text { Pengaruh } \\
\text { Tidak Langsung Melalui Y1 }\end{array}$ & Total \\
\hline $\mathrm{X} 1 \longrightarrow \mathrm{Y} 1$ & 0,011 & & 0,011 \\
$\mathrm{X} 1 \longrightarrow \mathrm{Y} 2$ & 0,564 & 0,161 & 0,725 \\
$\mathrm{X} 2 \longrightarrow \mathrm{Y} 1$ & 0,741 & & 0,741 \\
$\mathrm{X} 2 \longrightarrow \mathrm{Y} 2$ & 0,371 & 0,371 & 0,742 \\
$\mathrm{Y} 1 \longrightarrow \mathrm{Y} 2$ & 0,387 & & 0,387 \\
\hline
\end{tabular}

Sumber: Data diolah, 2019

tingkat penyerapan tenaga kerja yang relatif rendah dan lambat kenaikannya. Sepanjang tahun 2006 sampai dengan tahun 2010, ratarata pertumbuhan ekonomi sebesar 5,49 persen, dan rata-rata pertumbuhan tingkat penyerapan tenaga kerja sekitar 2,63 persen, suatu angka yang relatif kecil untuk dapat menyerap tenaga kerja yang setiap tahun terus meningkat. (Sulistiawati, 2012).

Pengeluaran pemerintah

$\left(\mathrm{X}_{2}\right)$ berpengaruh positif terhadap penyerapan tenaga kerja $\left(\mathrm{Y}_{1}\right)$. Yosi (2018) variabel pengeluaran pemerintah berpengaruh signifikan terhadap penyerapan tenaga kerja di Jawa Tengah tahun 1987-2016. Retno (2015) menunjukan variabel pengeluaran pemerintah berpengaruh signifikan positif terhadap penyerapan tenaga kerja terdidik serta penyerapan tenaga kerja tidak terdidik dan tidak terlatih. Pengaruh positif dari pengeluaran pemerintah begitu dirasakan oleh tenaga kerja tidak terdidik dan tidak terlatih.

Pengeluaran pemerintah $\left(\mathrm{X}_{2}\right)$ berpengaruh positif terhadap kesejahteraan masyarakat $\left(\mathrm{Y}_{2}\right)$. Dapat dijelaskan bahwa selama tahun 2000-2016, pengeluaran pemerintah berpengaruh langsung dansignifikan terhadapkesejahteraan masyarakat di Provinsi Bali. Hal ini menunjukkan adanya hubungan searah antara pengeluaran pemerintah dengan kesejahteraan masyarakat di Provinsi Bali, sehingga kenaikan pengeluaran pemerintah akan meningkatkan kesejahteraan masyarakat. Penelitian ini diperkuat oleh Sugiarto, Hamza dan Syechalad (2013) mengatakan Pengeluaran pemerintah berpengaruh signifikan terhadap IPM, dikarenakan setiap terjadi pertambahan pengeluaran pemerintah pada sektor kesehatan dan pendidikan sebesar satu persen dari total pengeluaaran pemerintah maka nilai IPM juga akan meningkat dan dapat meningkatkan kesejahteraan. Swaramarinda (2011) menyatakan kekuatan pengaruh pengeluaran pemerintah terhadap pembangunan manusia, harus bisa mengidentifikasi sektor prioritas seperti pendidikan dan kesempatan kerja yang mempunyai potensi paling tinggi untuk meningkatkan pembangunan manusia.

Penyerapan tenaga kerja $\left(\mathrm{Y}_{1}\right)$ berpengaruh positif terhadap kesejahteraan masyarakat $\left(\mathrm{Y}_{2}\right)$. Dwirainaningsih (2017) Berdasarkan hasil pengujian ini berarti bahwa hipotesis kedua yang diajukan dalam studi yaitu penyerapan tenaga kerja berpengaruh signifikan terhadap kesejahteraan masyarakat provinsi di Indonesia. Sulistiawati (2012) Penyerapan tenaga kerja berpengaruh signifikan dan mempunyai hubungan yang positif terhadap kesejahteraan masyarakat. Hal ini bermakna bahwa pengaruh penyerapan tenaga kerja terhadap kesejahteraan masyarakat berjalan searah, artinya apabila penyerapan tenaga kerja meningkat, maka akan meningkatkan kesejahteraan masyarakat.

Pertumbuhan ekonomi $\left(\mathrm{X}_{1}\right)$ tidak berpengaruh positif terhadap kesejahteraan masyarakat $\left(\mathrm{Y}_{2}\right)$. Menurut Sulistiawati, (2012). Pertumbuhan ekonomi tidak berpengaruh positif dan signifikan terhadap kesejahteraan masyarakat. Pertumbuhan ekonomi tidak berkualitas sehingga tidak membawa dampak pada peningkatan penyerapan tenaga kerja dan menjadikan kesejahtraan masyarakat menurun.

Hasil penelitian menunjukan bahwa pertumbuhan ekonomi tidak berpengaruh positif terhadap penyerapan tenaga kerja. Pertumbuhan ekonomi dianggap tidak berkualitas sehingga tidak membawa dampak pada penyerapan tenaga kerja, rendahnya kualitas pertumbuhan ekonomi 
diindikasi oleh tingkat penyerapan tenaga kerja yang relatif rendah dan lambat kenaikannya.

Hasil penelitian menunjukan bahwa pengeluaran pemerintah berpengaruh positif terhadap penyerapan tenaga kerja dan kesejahteraan masyarakat. Pengeluaran pemerintah meliputi pengeluaran untuk barang dan jasa yang dilakukan oleh pemerintah. Implikasi dari penelitian ini adalah pengeluaran pemerintah harus mulai di arahkan kepada pembangunan infrastruktur yang mampu memberikan kesempatan kerja bagi masyarakat di daerah, dengan menggunakan anggaran yang didistribusikan kepos-pos pendanaan yang tepat maka akan mampu menyerap tenaga kerja yang lebih banyak dan mampu mensejahterakan masyarakat di provinsi Bali.

Hasil penelitian ini menunjukan bahwa penyerapan tenaga kerja berpengaruh signifikan positif terhadap kesejahteraan masyarakat di kabupaten/kota provinsi Bali. implikasi dari penelitian ini adalah kesejahteraan masyarakat diharapkan akan terwujud apabila pertumbuhan ekonomi yang terus meningkat akan menciptakan lapangan kerja yang lebih banyak sehingga dapat menyerap tenaga kerja lebih banyak pada tingkat upah yang layak.

Hasil penelitian menunjukan bahwa penyerapan tenaga kerja memediasi terhadap pertumbuhan ekonomi di Kabupaten/kota provinsi Bali, sedangkan penyerapan tenaga kerja tidak memediasi terhadap pengeluaran pemerintah melalui kesejahteraan masyarakat di Kabupaten/kota Provinsi Bali.

\section{SIMPULAN DAN SARAN}

Pertumbuhan ekonomi memiliki pengaruh positif dan tidak signifikan terhadap penyerapan tenaga kerja sedangkan pengeluaran pemerintah memiliki pengaruh positif dan signifikan terhadap penyerapan tenaga kerja di Provinsi Bali tahun 2013-2017. Pengeluaran pemerintah dan penyerapan tenaga kerja memiliki pengaruh positif dan signifikan terhadap kesejahteraan masyarakat di Provinsi Bali tahun 2013-2017 sedangkan pertumbuhan ekonomi memiliki pengaruh yang tidak signifikan terhadap kesejahteraan masyarakat di Provinsi Bali tahun 2013-2017. Penyerapan tenaga kerja memediasi terhadap pertumbuhan ekonomi terhadap kesejahteraan masyarakat, sedangkan penyerapan tenaga kerja tidak memediasi pengaruh pengeluaran pemerintah terhadap kesejahteraan masyarakat di Provinsi Bali tahun 2013-2017.

Peneliti menyarankan kepada pemerintah daerah agar mengalokasikan dana pengeluaran pemerintah ke sektor-sektor yang lebih produktif karena dengan demikian akan mampu memperluas kesempatan kerja di Provinsi Bali. Disamping itu pemerintah juga harus menetapkan kebijakan agar berpihak kepada masyarakat, sehingga dengan ini mampu meningkatkan pertumbuhan ekonomi di Provinsi Bali. Diharapkan juga pemerintah daerah dapat mengalokasikan dana-dana yang di peroleh untuk upaya pembangunan daerah yang tepat sasaran melalui program-program yang menyentuh langsung pada kepentingan masyarakat seperti pendidikan dan kesehatan sehingga dapat mensejahterakan masyarakat di Provinsi Bali secara merata.

\section{REFERENSI}

Adipuryanti Y, Ni Luh Putu, Sudibya, I ketut. 2015. Analisis pengaruh Jumlah Penduduk Yang Bekerja Dan Investasi Terhadap Ketimpangan Distribusi Pendapatan Melalui Pertumbuhan Ekonomi Kabupaten/Kota Di Provinsi Bali. Jurnal PIRAMIDA Fakultas Ekonomi dan Bisnis Universitas Udayana (Unud), Bali, Indonesia. XI (1). 20-28.

Akudugu, Jonas Ayaribilla. 2012. Accountabillity in local Government revenue management: who does what?. Journal of Sustainable Development. 2(2). Arsyad, S. 2010. Konservasi Tanah dan Air. IPB Press. Bogor

Artana Y, I Komang Oka, \& Arka, Sudarsana. (2015). Pengaruh Pertumbuhan Ekonomi dan Disparitas Pendapatan Antardaerah Terhadap Kesejahteraan Masyarakat Provinsi Bali. Jurnal JEKT Jurusan Ekonomi Pembangunan Fakultas Ekonomi Dan Bisnis Universitas Udayana. 8(1). 63-71.

Dwirainaningsih, Yustiana. 2017. Pengaruh Upah Minimum Terhadap Penyerapan Tenaga Kerja Dan Kesejahteraan Masyarakat Di Kota Pekalongan. Hal:1-14. 
Edogbanya, Adejoh. 2013. Revenue Generation: Impact on Government Developmental Effort (AStudy of Selected Local Council in Kogi East Senatorial District). Global Journal of Management and Business Research.

Hukom, Alexandra. 2014. Hubungan Ketenagakerjaan Dan Perubahan Struktur Ekonomi terhadap Kesejahteraan Masyarakat. Jurnal JEKTJurusan Ilmu Ekonomi dan Studi Pembangunan Fakultas Ekonomi Universitas Palangka Raya. 7 (2). 120-129.

Jena, Pradeep Kumar. 2010. Indian Handicraft in Globlization Times: An Analysis Of Global-Local Dynamics. Interdisciplinary Description of Complex System. Journal Jawaharlal Nehru University, 8 (2), pp: 119-137.

Kaur, M., \& Singh, L. (2016). Knowledge in the economic growth of developing economies. African Journal of Science, Technology, Innovation and Development, 8(2), 205-212.

Mankiw, N. G,. Quah E,.and Wilson,P. (2013). Pengantar Ekonomi Makro, Asia ed. Jakarta, Indonesia:Selemba Empat.

Mirza, Denni Sulistio. 2012. Pengaruh Kemiskinan, Pertumbuhan Ekonomi, dan Belanja Modal Terhadap Indeks Pembangunan Manusia di Jawa Tengah 2006-2009. Jurnal Ekonomi Pembangunan, Fakultas Ekonomi, Universitas Negeri Semarang, EDAJ. Vol 1: hal, 1-15.

Nurrohman,Riyadi. 2010. Analisis Pertumbuhan ekonomi dan Penyerapan Tenaga kerja di Provinsi Jawa tengah. Fakultas Ekonomi Universitas Muhammadiyah Malang. 8(1). 248-260.

Nurudeen, A., and Usman, A. 2010. Government Expenditure and Economic Growth in Nigeria, 1970-2008: A Disaggregate Analysis. Business and Economic Journal. 4. Hal: 1-11

Patera, I Made, Suardana I Wayan. 2015. Model Hubungan Pariwisata , Kinerja Perekonomian Dan Kemiskinan Di Kabupaten Badung, Bali. Jurnal PIRAMIDA Alumni S3 Pariwisata Universitas Udayana. XI (2). 95-105.
Putri, Christina Hani dan Surya Dewi Rustariyuni. 2012. Analisis Struktur Perekonomian Bali: Pendekatan Shift Share. E-Jurnal EP Unud, 3(1), h: 111120.

Retno Wilis. (2015). Analisis Pengaruh Upah Minimum, Inestasi dan Pengeluaran Pemerintah Terhadap Penyerapan Tenaga Kerja Berdasarkan Pendidikan. El-Dinar, Vol 3, No 1, Januari 2015, hal 12-26.

Rustariyuni, Surya Dewi. 2014. Pengaruh Gini Ratio, Pengeluaran Non Makanan Per Kapita, Belanja Daerah Dan Laju Pertumbuhan Ekonomi Pada Indeks Pembangunan Manusia Kabupaten/Kota Di Provinsi Bali Periode 2004-2012. Jurnal PIRAMIDA Fakultas Ekonomi dan Bisnis Universias Udayana. X (1). 45-55.

Seyfriend, W., 2011, Examining the Relationship Between Employement and Economic Growth in the Ten Largest States, Southwestren Economic Review 2011, hal. 13-24, ONLINE.

Seran, Serilius. (2017). Hubungan Antara Pendidikan, Pengangguran Dan Pertumbuhan Ekonomi Dengan Kemiskinan. Jurnal JEKT Univesitas Timor(Unimor)-Fakultas Ekonomi dan Bisnis, 10(1). 59-71.

Suartha, Nyoman, Murjana Yasa, I Gusti Wayan. 2017. Pengaruh Pertumbuhan Ekonomi, Migrasi Masuk Terhadap Pertumbuhan Penduduk dan Alih Fungsi bangunan Penduduk Asli Kota Denpasar. Jurnal JEKT Universitas Udayana, 10(1). 95107.

Sukirno,Sadono. 2012. Makroekonomi Teori Pengantar Edisi Ketiga. Jakarta: Rajawali Pers.

Sulistiawati, Rini. 2012. Pengaruh Upah Minimum terhadap Penyerapan Tenaga Kerja dan Kesejahteraan Masyarakat di Provinsi di Indonesia. Fakultas Ekonomi Universitas Tanjungpura Pontianak. 8(3). 195-211

Swaramarinda Darma Rika dan Susi Andini. 2011. Pengaruh Pengeluaran Konsumsi Dan Investasi Pemerintah Terhadap Pertumbuhan Ekonomi Indonesia. Jurnal Ilmiah Econosains. 9(2). 95-105. 
Taufik,Muhammad, Rochaida, Eny, \& Fitriadi. (2014). Pengaruh Investasi Dan Ekspor Terhadap Pertumbuhan Ekonomi Serta Penyerapan Tenaga Kerja Provinsi Kalimantan Timur. Jurnal JEKT Fakultas Ekonomi Universitas Mulawarman. 7(2). 90-101.

Wijayanti, H.K.N., dan Darsana, I.B. 2015. Pengaruh Pendapatan Asli Daerah Dan Dana Alokasi Umum Terhadap Kesejahteraan Masyarakat Melalui Pertumbuhan Ekonomi(Studi Kabupaten/ Kota di Provinsi Bali Periode 2008-2013. Vol 5 No 12, Desember 20161462 2013). Jurnal Ekonomi Pembangunan Universitas Udayana, 4(5). h: 1164 - 1193.

Yosi, Rafica p., 2018, Pengaruh Pengeluaran Pemerintah, Pendidikan dan Investasi Terhadap Penyerapan Tenaga Kerja Di Provinsi Jawa Tengah. hal. 1-15. 